\title{
Escape from the Museum of Ethnography: the Right to Culture as the Core of the ECRML
}

\author{
Aleksandra Oszmiańska-Pagett \\ WYŻSZA SZKOŁA JĘZYKÓW OBCYCH \\ UL. RÓŻANA 17A, 61-577 POZNAŃ \\ MEMBER OF THE COUNCIL \\ OF EUROPE COMMITTEE OF EXPERTS \\ FOR THE EUROPEAN CHARTER \\ FOR REGIONAL OR MINORITY LANGUAGES \\ www. coe.int/minlang \\ oszmianka@yahoo.com
}

\begin{abstract}
(87 words)
The aim of this article is to explain the various aspects of the right to culture within the obligations contained in the ECRML. The presentation discusses the issues of cultural products, institutions, participation, linguistic landscape and intangible heritage. Consequently it is clear that the cultural dimension is present across various domains of public life covered by the Charter because its fundamental objective is to foster minority culture as part of life of a community, rather than just an aspect of folklore to be displayed in a museum.
\end{abstract}

\section{Introduction:}

\subsection{Aim}

The European Charter for Regional or Minority Languages (ECRML or Charter henceforth) is a Council of Europe convention, which is the only legally binding international covenant that entails not only negative but mainly positive language rights. In other words the signatory states are obliged not only to allow but also take active part in promoting the use of regional and minority languages (RMLs) in various domains of social life. The aim of this article is to explain how the right to culture is provided for in the particular obligations contained in the ECRML.

The structure of this presentation reflects the various aspects of cultural life and activity, rather than merely follow the order of articles contained in the Charter. In this way the intention of this publication is to shed light on what the right to culture can involve in reality, bearing in mind the fact that most international conventions that include culture, do not specify how this 
Aleksandra Oszmiańska-Pagett, Escape from the Museum of Ethnography: the Right to Culture as the core of the ECRML

right should be implemented/put into practice. "In fact, none of the international legal instruments provides a definition of cultural rights" (Donders 2016: 27). The presentation will finish with a few remarks on challenges that the technological advancements of the $21^{\text {st }} \mathrm{c}$. have created for the interpretation of the state obligations related to culture stemming from the Charter.

\subsection{Culture as a community's way of life}

Bringing up the issue of cultural rights inevitably leads to the problem of defining the concept of culture itself. For the purpose of this article, culture will be understood following Donder's interpretation which includes the following manifestations: cultural products, processes and cultural institutions. Additional aspects will include the issues of participation, linguistic landscape and language as intangible cultural heritage.

Donders concludes her perspective by saying that in this way culture can also be interpreted 'as a way of life' (Donders 2008: 2). This approach to culture is essential from the point of view of the Charter not only because it actually provides in a nutshell the cultural manifestations included in this convention. More importantly, on the one hand it takes us away from the elitist approach, where culture is seen as the higher form of artistic activity for the chosen, educated few. On the other hand, it also avoids the other extreme, usually associated with minority languages, i.e. the folkloristic approach. Both folklore and high culture are important but they do not exhaust the vast array of activities and process that are related to the RML community's cultural life.

\subsection{ECRML as a convention}

A few words on the structure and the workings of the ECRML as a convention will be presented here, as they are essential for further understanding of how the right to culture can actually be implemented. The obligations of the Charter are contained in two parts of this convention. Part II (Art.7) is a list of principles that all ratifying states are obliged to follow and for all RMLs that are present in their respective territory. Part III is divided into articles, each dealing with a different domain of language use (e.g. Art.8 Education, Art.9 Judicial authorities, Art.10 Administration, At.11 Media etc.). This part is designed to serve as 'menu', i.e. the ratifying state can choose the level of its commitment within each of the domains (e.g. the provision for an minority language TV channel vs. only TV programmes in minority language). Part of the obligation of the ratifying state is also to provide reports (every 3 years) on the level of the implementation of the undertakings selected, which then is analysed by the Committee of Experts which issues its conclusions in an Evaluation Report on the progress made.

\subsection{Right to culture within ECRML}


In fact the ECRML was conceived of as a convention protecting the European cultural heritage and diversity right from the point of its design. The reasoning used to justify the creation of a separate instrument of international law solely devoted to language was to safeguard RMLs "as cultural assets" (Woehrling, 2012: 23). As it is also confirmed in the preamble: “(...) the charter's overriding purpose is cultural. It is designed to protect and promote RMLs as a threatened aspect of Europe's cultural heritage [... and as] a living facet of Europe's cultural identity" (ECRML Explanatory Report: 5).

As a consequence the Charter does not invoke individual or group rights. Instead it "aims to safeguard language forms which are considered to have cultural value in themselves, and it develops legal rules for that purpose" (Woehrling, 2012: 21; ftn 6). In other words, the right to culture, from the Charter's perspective is about providing the opportunities for the speakers of RMLs, viewed "as possessors of cultural assets" (Woehrling, 2012: 21; ftn 6), and enable them to use their language in public life as a way to promote and protect the European cultural heritage. In turn, this obviously fosters the maintenance and development of a particular minority culture because the speakers can access it and contribute to it in various domains of social life.

This focal position of culture can be clearly seen in the content and structure of the Charter. The very first obligation contained in this convention obliges the state to recognise the RMLs "as an expression of cultural wealth" (Art. 7.1.a), which appears at the top the list of compulsory obligations that all ratifying states have to conform to (i.e. Part II). The same obligatory status is related to the separate article devoted to culture (Art. 12) in Part III. This article belongs to the list of obligatory articles of the convention that the state has to select from Part III of the convention when designing its ratification 'menu'.

Art.12 on Culture contains obligations regarding cultural products and various types of expression typical for the particular minority culture. It also caters for the institutional infrastructure and participation of the speakers in the organisation of various cultural activities. In other words, this article in itself almost exhausts the issue of what the right to culture can be interpreted as in the Charter's context. However, the cultural dimension can

be seen across other domains of language use in public, i.e. other articles of this convention. It is because the Charter sees the promotion of RMLs and their cultures as a set of interrelated processes, all of which will be discussed in detail below.

\subsection{Cultural products}

Explicit references to cultural products appear in Art.11 Media and Art.12 Culture. When it comes to the article on culture, the Charter requires from the state to encourage different "types of literary work and film production, vernacular forms of cultural expression, festivals" (Art. 12.1). This involves the obligation to foster access to these types of cultural expression which are specific to a particular RML (Art.12.1.a). However, the list of undertakings 
Aleksandra Oszmiańska-Pagett, Escape from the Museum of Ethnography: the Right to Culture as the core of the ECRML

includes also translation, dubbing, post-synchronisation and subtitling, both from and into a particular RML (Art. 12.1.b and c). In this way films or literary works 'specific for' particular minority culture can be accessed through a different language and therefore can be appreciated by those who do not know the particular RML. And vice versa, the obligation on translation makes it possible to enjoy cultural products of different minority communities, which are in turn translated into a particular RML. The intention here is again to foster contact and exchange between different communities, also from abroad, as well as exchange of cultural products between the RML and the dominant/official language of the state.

The idea of fostering cultural exchange between different communities also confirms the assumption, mentioned already above, that the aim of the Charter is for the minority culture to thrive and develop rather than stay in the form of a folkloristic 'fossil' for display in museums. The particular minority culture is supposed to keep up with time and appeal to all ages, which is also supposed to be secured through "the use of new technologies" (Art.12.1). The latter issue will be developed further in sec. 2.7 on challenges.

The issue of technology takes us obviously to the media, i.e. Art.11 of the Charter. The cultural products contained in this article include TV and radio productions, newspapers as well as audio and audio-visual works. However, the obligations listed for the state to choose from differ in their level of commitment, i.e. from the provision of the whole minority TV channel or radio station to the production of programmes; and from the whole newspaper (at least a weekly) in the RML to just articles written in the minority language.

The focus of the Charter is on the cultural products to be of a good quality, i.e. reflecting the culture "as a living experience of a community" (Oszmiańska-Pagett 2016: 256). In other words the content of TV or radio programmes as well as articles in the press, should not be merely limited to ethnographic presentations, but instead should reflect the recent developments in the cultural life of an RML community. The other essential factor is availability of media productions, which in the case of TV and Radio programmes refers to the frequency of broadcasts and for broadcast time to allow the reach of a wide diversified audience. Both of these are the main factors taken into account when evaluating the implementation of the obligations selected by the state (cf. Evaluation Report on Hungary 4(2010) paras. 163-164).

Obviously the Charter's understating of some of the cultural products, especially those related to media, is rooted in the late 1980's, i.e. the time when the convention was designed. This view is definitely outdated and needs revisiting from the perspective of the new media technologies available and in demand. This challenging issue will be discussed in sec.2.7 below.

\subsection{Cultural institutions}

Explicit call for the creation of institutions involved in minority culture is obviously made in Art. 12 (Culture), where the state is obliged to "encourage 
and/or facilitate the creation of body or bodies responsible for collecting, keeping a copy of and presenting or publishing works produced in RMLs" (Art.12.1.g). Various institutions that cater for cultural products are also listed at the very introduction to this article, i.e. "libraries, cultural centres, museums, archives, academies, theatres and cinemas" (Art.12.1).

However, the involvement of institutions in the cultural life is not only limited to their task of providing cultural products discussed in sec. 2.2 above. The Charter goes further and always insists on the active participation of the RML speakers in the functioning and decision making within such institutions.

This is clearly expressed in two obligations contained in Art.12 Culture. One of them requires cultural institutions involved in organising cultural activities to "have at their disposal staff who have a full command of the RML concerned" (Art.12.1.e). The other one involves the encouragement of "direct participation by representatives of the users of a given RML in providing facilities and planning cultural activities" (Art. 12.1.f). The same holds for provisions contained in Art.11 on Media, where the state is obliged to take into account the interests of RML speakers or their representation in the decision making of the broadcasting and programming boards (Art.11.3).

Here again it is obvious that the Charter sees the functioning of cultural institutions not merely as producers or keepers of cultural products but as bodies actively involved in the cultural life of a minority community, responding to the latest developments and needs of RML speakers, which obviously requires their participation discussed in the sc.2.4 below.

\subsection{Participation in culture}

As already explained in the section above, participation of RML speakers in planning and organising cultural activities is one of the most important aspects of fostering minority culture within the Charter obligations contained in Art. 11 and 12. This is also the exact approach taken up in the monitoring of the implementation of the Charter, where conclusion on the fulfilment of the obligations is always measured against the unique situation of each RML community and needs or concerns voiced by the RML speakers (ECRML (2004) 1; $1^{\text {st }}$ Evaluation Report on UK, Evaluation Report on Poland 1(2011), para. 108; Evaluation Report on Croatia 1(2001)).

Apart from direct involvement of RML speakers, participation in culture can also be interpreted as interest in particular cultural products and their availability. As it has been already discussed in sec. 2.2, in evaluation reports on the implementation of the Charter undertakings, cultural products are evaluated on the basis of their content quality and availability. Obviously good quality cultural products (literary works, artistic activity) will be available only if there is enough institutional and financial support, but most importantly if there is participation and contribution of the RML speakers. In this way the speakers are seen in the Charter process not merely as passive targets awaiting cultural products or events to 'be made for them' but 'with them'. 


\section{Aleksandra Oszmianska-Pagett, Escape from the Museum of Ethnography: the Right to Culture as the core of the ECRML}

Still another aspect of fostering cultural participation is the Charter's focus on cultural exchanges, which has already been mentioned with regard to undertakings related to translation both from and into an RML (sec. 2.2). The same assumption lies behind the obligation for the state to cater for "the maintenance and development of links, in the fields covered by the Charter, between groups using the same or similar RMLs [...] as well as the establishment of cultural relations with other groups in the state using different languages" (Art. 7.1.e). In other words the state is obliged to help in cultural exchanges between various minority communities that live in its territory. The same assumption lies behind the undertakings Art.12.2 and Art.12.3 on Culture. Paragraph 2 puts an obligation on the state to promote cultural activities in territories other than the traditional strongholds of a particular RML. Paragraph 3 requires to make provisions for RMLs in the state's cultural policy abroad. The importance of cultural exchanges abroad is also taken up in Art. 14 Transfrontier exchanges. The state is tasked with developing transnational contacts between states (Art.14.a) as well as between local communities in the border areas (Art.14.b) in order to cooperate in the field of culture and education.

To summarise, the issue of participation in cultural life is seen within the Charter as comprising: 1) availability and quality of cultural products, which trigger interest and demand; 2) direct participation of RML speakers on institutional level in planning and providing cultural activities and products; 3) cultural exchange between various RML groups through translation, transnational and cross-border cooperation.

Participation understood in such terms fosters the development of minority culture but is also part of a bigger process, i.e. makes an impact on the participation in culture in the society at large. This is possible because the Charter's obligations are designed in the way to engage the RML speakers and also make sure that the potential target audience will also be those who are not necessarily members of the particular minority (cf. Art. 7.1.e, Art.12.2, Art.12.3, Art. 14). The good quality and availability of minority culture is intended then to contribute to the participation in culture in general and for all, i.e. also the non-speakers of RMLs. Consequently, participation in minority culture fosters the development of social cohesion and citizens' participation in the society at large, not only within an RML community (cf. McGonagle \& van Eijk 2014: 31; Oszmiańska-Pagett 2015: 15-16; Cappello 2016: 11-12). This is obviously an idealistic scenario envisaged as an added value of the Charter process. In reality, implementing all the obligations and following the spirit of the Charter creates challenges for the states. They will be discussed in more detail in sec. 2.7 .

\subsection{Linguistic Landscape}

An important part of cultural heritage is obviously related to the traditional geographical areas of the RML communities. This is sometimes referred to as cultural landscape (UNESCO Operational Guidelines for the Implementation of the World Heritage Convention 2012) and is covered by the UNESCO World Heritage convention as well as the Council of Europe 
Faro Convention (Framework Convention on the Value of Cultural Heritage for Society 2005). For the Charter's perspective with language in focus, a more appropriate term would be linguistic landscape (Landry \& Bourhis 1997).

The wording of the undertaking in the Charter obliges the state to encourage: "the use and adoption, if necessary in conjunction with the name in the official language(s), of traditional and correct forms of place-names in RML" (ECRML Text of the Charter, Art.10.2.g). In states that have selected this obligation is usually implemented through the establishment of bilingual names of towns, villages or welcome signs. But in fact, the undertaking envisages the use and display of all traditional topographical names and signage. This includes names of streets, squares, names all types of physical objects (sites, monuments, public buildings) as well as elements of natural landscape (mountains, rivers, lakes etc.) (Woehrling, 2012: 193).

As a consequence, on the one hand the implementation of this undertaking involves bringing back 'old' names that might have been removed or even banned in the course of historical and political struggles. In this sense the purpose of the undertaking is "to bear witness to the traditional presence of a language on a particular territory" (Woehrling, 2012: 193). On the other hand, following the spirit of the Charter whose aim is to make minority languages a living means of communication, it could also involve coming up with the equivalents in RML of newly-established names in public use (Engbers 2012: 354-355; Woehrling, 2012: 193).

The use of both old and new signage in a particular RML justifies in the Charter's context the use of the term linguistic landscape which is supposed to stand for the presence of various languages in public signs of all types (Landry \& Bourhis 1997, Gorter 2006). Consequently linguistic landscape in the Charter's context should be a reflection of not only the 'old forgotten world' but an up-to-date language environment of public space. This takes us to one more undertaking of the Charter that at face value has little to do with cultural life, but being a part of linguistic landscape deserves a mention here. This is the obligation for the RML to be used in the provision of public services (Art.10.3.a). Public transport is the most relevant example for the issue at stake here. All the information displayed on buses, trams or trains, related to routes, schedules and even ticketing could be provided in the particular RML (Woehrling, 2012: 196), especially because it would involve the use of place names discussed above. In this sense linguistic landscape fostered by the Charter extends from display outdoors ('in the street') to display inside the public service buildings and means of transport.

The vision presented above and envisaged as the result of obligations stemming from the Charter is obviously again far from being turned into reality, i.e. fully implemented by the states. Interestingly enough even the most frequent realisation, i.e. bilingual place names, remains a contested issue. The existing signs have been reported to be vandalised (ECRML (2011)5, 1st Evaluation Report on Poland), or local RML communities struggle with negative attitudes within their areas toward putting up signs in their language. How important and at the same controversial this display 
Aleksandra Oszmiańska-Pagett, Escape from the Museum of Ethnography: the Right to Culture as the core of the ECRML

of RML presence may be in a particular state context, is also reflected by the fact that out of 25 states which ratified the Charter, 5 did not select Art. 10.2.g on traditional place names, among them Austria and Denmark1.

\subsection{Language as Intangible Cultural Heritage}

The final aspect of the Charter's perspective on the right to culture presented in this publication deals with the provision of culture in education. Language is considered an essential vehicle of intangible cultural heritage so the very provision of teaching in or of an RML as envisaged by the Charter is an obvious contribution to protecting this heritage. The teaching covers all levels of education, from compulsory to vocational and university education. However, this presentation will only focus on those obligations contained in the Charter, especially from Art.8 Education, that are especially/directly relevant to culture.

Art.8.1.g obliges the state to "ensure the teaching of the history and culture which is reflected by the RML" (ECRML Text of the Charter, Art.8.1.g). This is the main obligation that makes an explicit mention of the necessity to teach about a minority culture and history of an RML community. The important aspect of this obligation is that its fulfilment requires not only the provision of such teaching for children of the RML background, but even more importantly for children in mainstream education. This requirement has been frequently reiterated in the evaluation reports (ECRML (2015) 3, $3^{\text {rd }}$ Evaluation Report on Montnegro: para.84). It is seen as an essential contribution to the mutual understanding between different RML groups in the state as well as awareness raising mechanism for the mainstream society. This approach is also evident in another obligation for the state "to promote the inclusion of respect, understanding and tolerance in relation to RMLs" (ECRML Text of the Charter, Art.7.3) which should be part of objectives in education as well as mass media content.

The final example of education's contribution to cultural life and traditions of an RML community comes from an undertaking regarding vocational training. Interestingly enough its relevance to culture is not reflected in the wording of the undertaking itself, but has become obvious through the years of the monitoring process of its implementation. The case of the Sami communities is the best example here, where vocational education caters for passing on the skills and knowledge related to reindeer herding and traditional handcrafts, an obvious example of intangible heritage (ECRML (2011)4, 4th Evaluation Report on Sweden: para.114).

\subsection{Contemporary challenges in implementation}

Having presented the Charter's interpretation of what can be considered various aspects of the right to culture, it is important to point to some challenges and problems in turning this idealistic vision into reality. They

1 The other states are Lichtenstein, Luxemburg and Cyprus. In all three cases the instrument of ratification simply does not include selected undertakings from Part III of the Charter. 
can be categorised into three groups: technical/practical problems related to implementation, attitudes to minority culture and finally the technological advancements of the $21^{\text {st }} \mathrm{c}$.

The practical recurring problem stems from the ratification instrument, i.e. the list of selected obligations from Part III of the Charter. This selection can be either too limited (Denmark) or the opposite, overambitious (BosniaHerzegovina, Poland), both of which create great problems in providing for the promotion of RMLs. Lack of funding and well-planned strategy on how to put the obligations stemming from the Charter into practice, are among the most frequent problems, too.

However, the obstacle that seems to be most relevant for the full implementation of the right to culture as envisaged by the Charter's idealised vision, lies on a more abstract level of attitudes towards RML cultures and the dominant culture of the state. Minority cultures are still treated from the position of 'old traditions', rather than living experience of contemporary RML communities. This approach stems from a lack of awareness on the part of the mainstream society about the minority cultures and languages (recurring Recommendations). Minority cultures are still not seen as part of common heritage of the society within the state, but either as folkloristic attraction or worse, as an enemy within (cf. acts of intolerance and vandalism). Participation in minority culture is then organised for the minority to help them meet their needs, rather than from the perspective of a common social benefit, as if the minorities lived in isolated territorial bubbles.

Another challenge stems from technological advancements in communication, which challenge the 'traditional' understanding of participation in and access to culture. With contemporary societies across Europe experiencing high level of mobility, cultural participation and identification exceeds not only particular localities, but also the traditional boundaries of the national culture. "The world of self-contained, homogenous speech communities based on strong direct bond/ties, ceased to exist" (Dołowy-Rybińska 2017: 12) ${ }^{2}$ This is true especially from the point of view of the young generation, who can engage in communication and communities of practice literally across the globe. As a consequence "(...) the term access is no longer used to describe the rights of visits to a museum, an archaeological site or a concert. Instead, today it is commonly used to describe the right of individuals to enjoy an electronic reproduction of a cultural good (...) whenever and in any way they please" (de Hert 2016: 34).

If RMLs and their cultures are to survive and more importantly thrive, then they have to respond to these changes. And in fact they are trying to, i.e. there are young RML activists who are involved in making sure their language does not remain a fossilised language of the ancestors but is a living means of communication also in their peer group. Fortunately they

2 "Świat zamkniętych, homogenicznych wspólnot językowych opartych na silnych bezpośrednich więziach przestał istnieć” (Dołowy-Rybińska 2017: 12) 


\section{Aleksandra Oszmiańska-Pagett, Escape from the Museum of}

Ethnography: the Right to Culture as the core of the ECRML

are aware of the importance of their own participation in the process, as summarised in the witty title "Nobody else will do it for us" [Nikt za nas tego nie zrobi] of a monograph on young Breton, Kashubian and Welsh activists by Dołowy-Rowińska (2017). Paradoxically the same communication technology that contributes to the demise of local communities can work to the benefit of the RML 'cultural production' which can now break local boundaries easier and cheaper.

At the same time this also challenges the monitoring of the implementation of the Charter obligations, especially with reference to the new media. It raises important questions such as: What counts as a newspaper or a newspaper article online? How to weigh the RML coverage on the Internet against the age structure of the RML group? Is there enough digital literacy among the members of the RML community for the online access? All this also has to be measured against the background of the technological development of the particular state, e.g. the availability of broadband Internet, the level of digitalisation etc. All these questions have already become an indispensible part of the Charter's monitoring process and a work on revisiting the interpretation of some of the culture and media obligations is already under way.

\subsection{Conclusion}

As it has been shown in this presentation, the Charter caters for the right to culture across a variety of its obligations, i.e. Art.11 Media and Art.12 Culture (cultural products and institutions), Art.10 Administration (linguistic landscape), in Art. 7.1.a and Art.8 Education (intangible cultural heritage). The Charter puts great emphasis on participation in culture, not only on the part of the RML speakers, but also the members of the mainstream society (Art. 7.1.e). Cultural exchanges are also a vital contribution to mutual understanding and the awareness of the linguistic and cultural diversity (Art.14 Transfrontier exchanges). The quality of cultural products as well as ways to access them are seen as essential factors contributing to the development and promotion of RMLs and their cultures. Minority languages as vehicles of intangible heritage are also supposed to serve their speakers as a living means of communication and minority culture as reflecting not only the traditions but also up-to-date experiences. Only through active participation of RML speakers and awareness of the value of diversity within the mainstream society, can the minority culture escape the museum of ethnography and keep up to date with the contemporary online communication technology. 
Investigationes Linguisticae, vol. XLII

\section{Bibliography}

Cappello, M. (ed.) 2016. Regional and local broadcasting in Europe, IRIS Special. Strasbourg: European Audiovisual Observatory.

De Hert, P. 2016. Access to Culture, Media, Information in the Digital Age w: A. Wiesand, K. Chainoglou, A. Śledzińska-Simon, Y. Donders (eds.) Culture and Human Rights: The Wroclaw Commentaries. Berlin: De Gruyter. pp. 33-40.

Dołowy-Rybińska, N. 2017. Nikt za nas tego nie zrobi. Toruń: Wydawnictwo Naukowe UMK.

Donders, Y. 2008. Cultural Life in the Context of Human Rights. Geneva: UN. http://www.ohchr.org/Documents/HRBodies/CESCR/Discussions/May2008/Y vonneDonders.pdf 
Aleksandra Oszmiańska-Pagett, Escape from the Museum of Ethnography: the Right to Culture as the core of the ECRML

Donders, Y. 2016. Cultural Diversity and Cultural Identity in Human Rights. w: A. Wiesand, K. Chainoglou, A. Śledzińska-Simon, Y. Donders (eds.) Culture and Human Rights: The Wroclaw Commentaries. Berlin: De Gruyter. pp. 2332.

Engbers, J. 2012. Administrative authorities and public services, w: Nogueira Lopez, A.N., Ruiz Vieytez, E.J., Urrutia Libarona I.U. XXXXX

ECRML Explanatory Report 1993. Strasbourg: Council of Europe Publishing.

ECRML Text of the Charter. Strasbourg: Council of Europe Publishing. http://...

ECRML (2011) 5, 1st Evaluation Report on Poland:

http://www.coe.int/t/dg4/education/minlang/Report/EvaluationReports/Pol andECRML1_en.pdf

Evaluation Report on UK 1(2004); Evaluation Report on Poland 1(2011), para. 108; Evaluation Report on Croatia 1(2001)).

Framework Convention on the Value of Cultural Heritage for Society 2005 (Faro Convention). https://www.coe.int/en/web/conventions/full-list//conventions/rms/0900001680083746

Gorter, D. 2006. Introduction: The Study of the Linguistic Landscape as a New Approach to Multilingualism, w: Gorter, Durk (ed.) Linguistic Landscape: a new approach to multilingualism, Clevendon: Multilingual Matters, 1-6.

Landry, R., Bourhis, R. Y. 1997. Linguistic landscape and ethnolinguistic vitality: An empirical study, Journal of Language and Social Psychology 16 (1), 2349 .

McGonagle, T., van Eijk, N. 2014 The role of regional media as a tool for building participatory democracy. Amsterdam: University of Amsterdam. https://www.ivir.nl/publicaties/download/regional-media-and-participatorydemocracy.pdf

Oszmiańska-Pagett, A. 2015. The protection of children's rights under the European Charter for Regional or Minority Languages. Strasbourg: Council of Europe.

Oszmiańska-Pagett, A. 2016. Regional and Minority Languages. w: A. Wiesand, K. Chainoglou, A. Śledzińska-Simon, Y. Donders (eds.) Culture and Human Rights: The Wroclaw Commentaries. Berlin: De Gruyter. pp. 255-257.

UNESCO Operational Guidelines for the Implementation of the World Heritage Convention 2012.

Woehrling, J. M. 2005. The European Charter for Regional or Minority Languages. A Critical Commentary. Strasbourg: Council of Europe Publishing. 
Investigationes Linguisticae, vol. XLII 